\title{
School Counselors' Attitudes Regarding Counseling Interventions Conducted Prior to Reporting Sexual Abuse
}

\section{Research Article}

\section{Sahabettin MUTLU ${ }^{1}$, Zohre KAYA ${ }^{2}$}

${ }^{1}$ Ministry of Education, Van, Turkey, ORCID:0000-0002-5521-2022

${ }^{2}$ Van Yuzuncu Yal University, Faculty of Education, Department of Guidance and Counseling, Van, Turkey, ORCID: 0000-0001-9211-3632

To cite this article: Mutlu, S., \& Kaya, Z. (2020). School Counselors' Attitudes Regarding Counseling Interventions Conducted Prior to Reporting Sexual Abuse, International Online Journal of Educational Sciences, 12(3), 164-176.

\begin{tabular}{l} 
ARTICLE INFO \\
\hline Article History: \\
Received 08.08.2019 \\
Available online \\
07.07 .2020
\end{tabular}

\begin{abstract}
This study seeks to identify psychological counselors' attitudes regarding other point used when dealing with cases of sexual abuse and to reveal related prominent themes. The study group was composed of 22 psychological counselors employed in different school levels throughout the township of Erciş located in province of Van, Turkey and who have dealt with at least one instance of sexual abuse during their career. Following a mixed-method design, this study used the $Q$ method to collect data. While quantitative data were analyzed using the PQ Method, qualitative data were analyzed using Thematic Analysis. Examination of the study's findings reveals that although psychological counselors exhibited two different attitudes regarding the interventions they used when dealing with cases of sexual abuse, these two attitudes were not independent of each other. According to the findings the most prevalent interventions used by psychological counselors were to emphasize that the child's body was valuable, to iterate the child's innocence, and to remain flexible during the process whereas the most undesired interventions were to force the child to speak and to end the dialogue. It was found upon further examination of the counselors' statements regarding the issue that the two themes most referred to by counselors were directing the process in an appropriate manner and notification.
\end{abstract}

(ㄷ) 2020 IOJES. All rights reserved

Keywords:

Sexual abuse, Psychological counselor, Counseling interventions, Q method

\section{Introduction}

Child sexual abuse (CSA) is defined as the involvement of children or adolescents in a sexual activity with an adult individual that they do not fully comprehend or for which they are not developmentally prepare (Bulut, 2018). Despite there being no clear boundary as to which behaviors constitute CSA, kissing children

${ }^{2}$ Corresponding author's address: Kazım Karabekir Primary School, Van, Turkey Telephone: +905066175055

e-mail: alsancak-65@hotmail.com

DOI: https://doi.org/10.15345/iojes.2020.03.013 
on the lips, fondling their breasts or genitalia, having a child fondle oneself, child voyeurism, and engaging in direct sexual contact are accepted as major sexual abuse behaviors (Bulut, 2016). CSA is a serious social problem that precipitates deeply negative outcomes in society and that impedes an individual subject to it from forming a healthy bond with the greater community (Çeçen, 2007).

A character type ready to use anything and everything for his own personal gratification has emerged as a result of the negative impact on the family structure and the decline in importance given to divine morals caused by rapid changes worldwide. Children's weak and defenseless nature renders them helpless victims to this type of person. Consequently, cases of CSA have witnessed an ever-rising increase in number (Bulut, 2016). Despite findings showing cases of CSA to be more wide-spread in North American and Western Europe, it is thought that accurate prevalence rates for every country and culture have yet to be attained because societies and families in many countries conceal and refrain from reporting the occurrence of such events (Moore, 2005; Güneş, 2002). Although studies on this specific issue are limited in Turkey, a significant increase in cases of CSA can be observed by looking at the existing statistics and at the number of cases brought to judicial authorities (Gündüz \& Yıldız, 2012). According to data by the Turkish Statistical Institute (TÜIK), the number of sexual abuse cases brought to judicial authorities in Turkey was 74,064 and 83,552 in 2014 and 2016, respectively (Polat, 2018).

Sexual abuse is considered the most difficult of all types of abuse to expose. Both threats made to children and efforts by most families to conceal occurrences of CSA upon learning of them constitute serious obstacles to their disclosure (Polat, 2007). Another serious impediment to such events' disclosure is the intense amount of anxiety experienced by children as a result of their statements regarding sexual abuse being approached with doubt (Alaggia, 2004). Another important factor deterring the disclosure of such occurrences is when it is perpetrated by a family member (Gümüş, 2017).

A child subject to sexual abuse has difficulty not only recounting the event to others but also seeking help from others. It is therefore important that teachers and school counselors observe students in their schools and communicate with children in the event that they to recognize a negative turn in the child (Alaggia, 2004). The vast majority of sexual abuse cases are uncovered by school counselors following conversations had with children. Using appropriate counseling interventions, psychological counselors are able facilitate the disclosure of sexual abuse subjected to a child through these conversations (Lyon \& Ahern, 2011). Accordingly, it is important that training programs be developed teaching psychological counselors how to respond to cases of sexual abuse and what counseling interventions they should use in such cases. We believe that by identifying the counseling interventions currently used by psychological counselors and their attitudes related to the issue at hand, an invaluable data source will be constructed that may be used in the preparation of these training programs.

An examination of the literature reveals that studies have been conducted investigating: (i) psychological counselors' practices regarding the reporting of sexual abuse cases (Gümüş, 2017), (ii) teachers' experiences in this subject (Aksel \& Irmak, 2015), and (iii) potential training and educational programs (Çeçen, 2007; Gündüz \& Yıldız, 2016). However, no study was found to investigate the attitudes of psychological counselors towards counseling interventions used in this regard. Accordingly, this study attempts to determine whether school counselors have reached a consensus regarding their interventions to the sexual abuse cases brought to their attention, what counseling interventions are most prevalent, and prevailing themes related to this issue. To this end, it answers to the following questions have been sought:

1. Is there a consensus by school counselors regarding counseling interventions for sexual abuse cases?

2. What are the most prevalent counseling interventions used by school counselors during their interviews with children subject to sexual abuse. 
3. What are school counselors' attitudes on how to prevent cases of sexual abuse and on how to disclose those that have occurred?

\section{Material and Method}

\section{Research Model}

A mixed-method case study was used to answer the study questions. Adopting both quantitative and qualitative research approaches, mixed-method studies allow researchers to benefit from both types of data in their analyses (Büyüköztürk, Çakmak, Akgün, Karadeniz, \& Demirel, 2017). We used the Q method, a type of analysis used to measure individuals' attitudes and perceptions, to collect data for this study. In the analysis, individuals are grouped under specific factors based on the proximity of their opinions. The basic approach to the Q method is to arrange participants' thoughts on a string at appropriate positive and negative intervals. This string is constructed in one of two methods: (i) the free method, in which participants are able to place however many sentences they want under whatever number they want, and (ii) the forced method, in which the researcher determines beforehand how many judgment sentences may be placed under each number (Demir \& Kul, 2011). In this study, participants were asked to rank items according to the forced method. The Q string used for the Counseling Interventions Survey is presented in Figure 1.

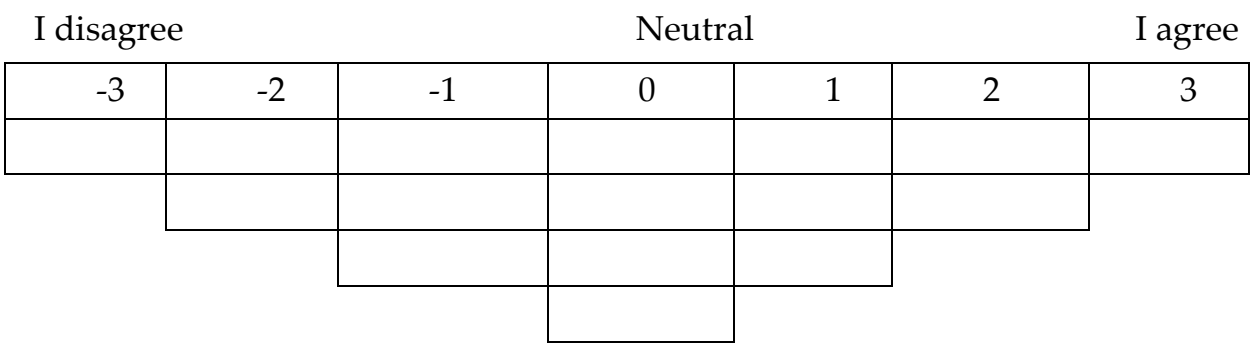

Figure 1. Q String

The study group was formed using criterion sampling. In this method, units corresponding to predetermined criteria were used to form the sample (Büyüköztürk, Çakmak, Akgün, Karadeniz, \& Demirel, 2017). The criterion for counselors' inclusion in the study group was to have dealt with at least one sexual abuse case. A total of 22 psychological counselors employed throughout the township of Erciş located in the province of Van, Turkey who fulfilled this criterion were included in the study group. The demographic variables of the counselors participating in the study are presented in Table 1.

Table 1. Participants' Demographic Information

\begin{tabular}{llll}
\hline Variables & & $\mathbf{n}$ & $\mathbf{\%}$ \\
\hline \multirow{2}{*}{ Gender } & Male & 12 & 54.5 \\
\cline { 2 - 4 } & Female & 10 & 45.5 \\
\hline \multirow{2}{*}{ School Type } & Primary & 5 & 22.7 \\
\cline { 2 - 4 } & Middle & 7 & 31.8 \\
\cline { 2 - 4 } & High School & 10 & 45.5 \\
\hline \multirow{2}{*}{$\begin{array}{l}\text { Sength of } \\
\text { Service }\end{array}$} & 1-4 years & 13 & 59.1 \\
\cline { 2 - 4 } & 5-8 years & 6 & 27.3 \\
\cline { 2 - 4 } & 9 years and more & 3 & 13.6 \\
\hline
\end{tabular}




\section{Data Collection Tools and Procedures}

\section{Psychological interventions survey}

The researcher used structured design, one of the various $Q$ method techniques, to collect data for the study. Since in structured design, it is necessary to base items in the literature, the Counseling Interventions Survey was developed taking the literature as its basis. A draft survey was developed after conducting a review of the literature, which was then submitted to expert opinions to bring the survey to its final 16-item form. The Counseling Interventions Survey is presented in Appendix 1 at the end of this study.

\section{$Q$ string and question cards}

In this study, the 16 questions included in the Counseling Interventions Survey were made into carts and a $Q$ string was drawn on large-sized cardboard display board. The psychological counselors were first given the Counseling Interventions Survey and asked to read it during the face-to-face interviews. They were then asked to arrange the carts on the Q string based on their order of priority. Data were recorded after each interview. Open-ended questions were added to the forms used to collect data in order to obtain more detailed information from counselors. Each participant was assigned a letter and their demographic information was recorded together with the $\mathrm{Q}$ string. The data collection process took approximately 20-30 minutes for each participant.

\section{Data Analysis}

In this study, analyses pertaining to participants' frequencies and percentages were conducted. The data attained were analyzed using the PQ Method program downloaded from http://schmolck.userweb.mwn.de/qmethod/. Because a $\mathrm{p}<.05$ level of significance was sought, the formula $1 / \sqrt{ }$ n (number of people) x 1.96 (McKeown \& Thomas, 2013) was used in the distribution of participants' statistically significant factors. A value of .417 was obtained from this formula for the 16-question Counseling Interventions Survey and was accepted as the criterion in the distribution of participants. In other words, a participant was evaluated under the factor with which he had a correlation value of .417 or greater.

Thematic analysis, one of the content analysis methods, was used to analyze qualitative data. In thematic analysis, analytical techniques are used to search for themes and patters in the data collected (Liamputtong, 2009). In this study, psychological counselors' answers to the open-ended questions asked regarding the subject were examined and main themes were identified. Participants' responses to the questions asked to them were included verbatim when describing the themes discussed in this study.

\section{Findings}

\section{Quantitative Findings}

Data collected from the psychological counselors participating in the study were analyzed using the PQ Method program. As a result of the analysis, participants' opinions were grouped under 2 factors at a significance level of $\mathrm{p}<.05$. Data belonging to the factors under which participants were distributed are presented in Table 2.

Table 2. Factor Distribution of Counselors' Opinions

\begin{tabular}{llllll}
\hline Participant & Factor $\mathbf{1}$ & Factor 2 & Participant & Factor $\mathbf{1}$ & Factor 2 \\
\hline $113 \mathrm{Z}$ & $\mathbf{0 . 6 7 9 1 X}$ & -0.1021 & $131 \mathrm{~K}$ & 0.2091 & $\mathbf{0 . 6 9 6 7 X}$ \\
\hline $123 \mathrm{Y}$ & $\mathbf{0 . 6 7 9 8 X}$ & 0.5156 & $122 \mathrm{~J}$ & $\mathbf{0 . 7 2 6 3 X}$ & 0.6066 \\
\hline $123 \mathrm{~V}$ & $\mathbf{0 . 9 2 6 0 X}$ & 0.0765 & $221 \mathrm{I}$ & 0.6142 & $\mathbf{0 . 6 5 0 9 X}$ \\
\hline $131 \mathrm{~T}$ & $\mathbf{0 . 7 0 9 9 X}$ & 0.5547 & $132 \mathrm{H}$ & $\mathbf{0 . 6 6 5 4 X}$ & 0.4890 \\
\hline $231 \mathrm{~S}$ & 0.3262 & $\mathbf{0 . 8 2 7 5 X}$ & $112 \mathrm{G}$ & $\mathbf{0 . 6 8 6 4 X}$ & 0.3868 \\
\hline $221 \mathrm{R}$ & 0.2277 & $\mathbf{0 . 7 3 3 8 X}$ & $121 \mathrm{~F}$ & -0.1024 & $\mathbf{0 . 8 3 5 6 X}$ \\
\hline
\end{tabular}




\begin{tabular}{llllll}
\hline $211 \mathrm{P}$ & $\mathbf{0 . 7 4 9 4 X}$ & 0.0041 & $231 \mathrm{E}$ & 0.4265 & $\mathbf{0 . 8 0 4 8 X}$ \\
\hline $231 \mathrm{O}$ & $\mathbf{0 . 6 2 6 6 X}$ & 0.5684 & $221 \mathrm{D}$ & $\mathbf{0 . 7 7 7 9 X}$ & 0.3968 \\
\hline $132 \mathrm{~N}$ & 0.3093 & $\mathbf{0 . 5 9 1 9 X}$ & $112 \mathrm{C}$ & 0.0201 & $\mathbf{0 . 8 5 5 3 X}$ \\
\hline $231 \mathrm{M}$ & $\mathbf{0 . 6 7 4 9 X}$ & 0.5999 & $132 \mathrm{~B}$ & 0.4552 & $\mathbf{0 . 6 9 1 2 X}$ \\
\hline $231 \mathrm{~L}$ & $\mathbf{0 . 6 8 4 8 X}$ & 0.5631 & $211 \mathrm{~A}$ & $\mathbf{0 . 7 1 5 1 X}$ & 0.3759 \\
\hline
\end{tabular}

Table 2 illustrates that of the total 22 participants, 13 were grouped under the Factor 1 and 9 were grouped under the Factor 2. All participants were included in a factor. The results of the correlation analysis conducted to determine the relationship between factors are presented in Table 3 .

Table 3. Relationship between Factors

\begin{tabular}{lll}
\hline & Factor 1 & Factor 2 \\
\hline Factor 1 & 1.0000 & 0.6135 \\
\hline Factor 2 & 0.6135 & 1.0000 \\
\hline
\end{tabular}

Table 3 illustrates that the there is a strong, statistically significant and positive relationship between Factors 1 and 2, indicating that the two factors resemble each other. Items' Z-scores and order of priority for both factors are presented in Table 4.

Table 4. Items' Z-scores and Order of Priority

\begin{tabular}{|c|c|c|c|c|}
\hline \multirow{2}{*}{ Items } & \multicolumn{2}{|c|}{ Factor 1} & \multicolumn{2}{|l|}{ Factor 2} \\
\hline & Z-score & Rank* & Z-score & Rank* $^{*}$ \\
\hline 12-An understanding that one's body is valuable belongs to him & 1.863 & 1 & 0.833 & 3 \\
\hline $\begin{array}{l}\text { 1- Being flexible in order to obtain accurate information and to be } \\
\text { helpful. }\end{array}$ & 1.299 & 2 & 0.535 & 6 \\
\hline 2- Insisting when the child does not want to talk about the event. & 0.965 & 3 & -0.229 & 11 \\
\hline 13-Instilling in children that they are innocent. & 0.662 & 4 & 1.649 & 1 \\
\hline $\begin{array}{l}\text { 16-Paying attention to the messages that children's body language } \\
\text { convey during conversations with them. }\end{array}$ & 0.557 & 5 & 1.071 & 2 \\
\hline 8-Recognizing signs of trauma. & 0.555 & 6 & 0.256 & 9 \\
\hline 15-Considering it normal for children to reflect their anger externally. & 0.432 & 7 & 0.800 & 4 \\
\hline $\begin{array}{l}\text { 9-Using indirect methods to extract information from very young } \\
\text { children. }\end{array}$ & -0.025 & 8 & 0.298 & 8 \\
\hline $\begin{array}{l}\text { 11-Informing children that the same event could happen o other } \\
\text { children. }\end{array}$ & -0.122 & 9 & 0.741 & 5 \\
\hline 7-Holding in-depth conversations to prove abuse. & -0.172 & 10 & -0.848 & 13 \\
\hline 5-Using scientific vernacular during conversations. & -0.283 & 11 & -0.821 & 12 \\
\hline $\begin{array}{l}\text { 10-Ending dialogue after extracting an account of the event and } \\
\text { passing it on to the necessary authorities. }\end{array}$ & -0.434 & 12 & -1.775 & 16 \\
\hline $\begin{array}{l}\text { 6-Using closed-ended or leading questions to obtain accurate } \\
\text { information from children. }\end{array}$ & -0.951 & 13 & 0.460 & 7 \\
\hline 14-Using exposure techniques when speaking with children. & -1.174 & 14 & -1.241 & 14 \\
\hline 3-Speculating in such a way that implies the existence of sexual abuse. & -1.453 & 15 & -0.168 & 10 \\
\hline 4-Forcing a child who refuses to recount the event to spe & -1.720 & 16 & -1.561 & 15 \\
\hline
\end{tabular}

*Indicates the item's order of priority in its respective factor as attributed by participants.

As seen in Table 4, the most influential items in Factor 1 are (\#12) to instill in children and adolescents subject to sexual abuse an understanding that their bodies are valuable and belong to them alone and (\#1) each sexual abuse case has its own conditions particular to it and one must be flexible in order to obtain accurate 
information and to be of help. The least influential items in Factor 1 are (\#3) encouraging the child to speak by reacting and making speculations in such a way that imply the existence of sexual abuse and (\#4) forcing a child subject to sexual abuse to tell the truth if he wants to end the conversation.

Upon further review of Table 4, it is observed that the most influential items in Factor 2 are (\#13) giving children subject to sexual abuse the message that they are innocent and (\#16) paying attention to the messages one's body language gives while communicating with children subject to sexual abuse. The least influential items in Factor 2 are (\#4) forcing a child subject to sexual abuse to tell the truth if he wants to end the conversation and (\#10) ending conversations upon receiving the story of how the event transpired and passing information to the necessary authorities.

\section{Qualitative Findings}

An analysis of the qualitative data revealed 7 sub-themes grouped under the 3 main themes of (i) most preferred counseling interventions, (ii) undesired counseling interventions, and (iii) counselors' attitudes on the issue. Main themes and subthemes are shown in Figure 2.

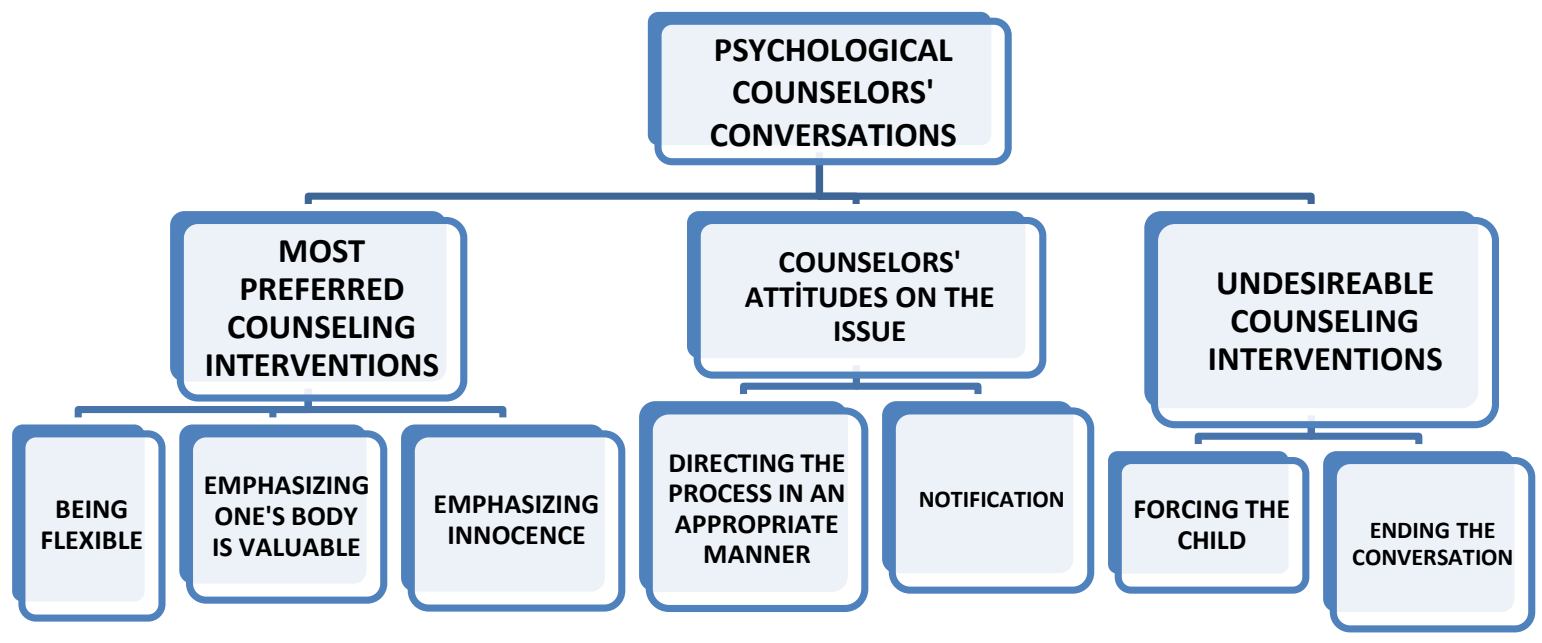

Figure 2.Themes Related to Counseling Interventions Used during Cases of Sexual Abuse

\section{Theme 1: Emphasizing one's body is valuable}

The most used intervention by counselors when responding to cases of sexual abuse is to instill in the child the notion that his body is valuable and belongs to him. Counselors stated that because children subject to sexual abuse perceive their bodies to be worthless and unclean, they first need to make children feel that their bodies are valuable in order to be of help to them. Example statements by the participants include:

A child subject to sexual abuse generally becomes alienated from his body and feels worthless, perceiving himself to have a body that he should be ashamed of. As such, we absolutely have to instill in the child the notion that his body is valuable. (231M)

He have to make children feel that their bodies are valuable and belong solely to themselves. This consciousness enables them to express instances of abuse and serves as a precaution protecting children from the possibility of being subject to abuse. (131K)

\section{Theme 2: Being flexible}

One of the more frequently used interventions used by counselors in order to extract information from children and to be helpful to them is to be flexible. Since children's reactions and the signs of abuse are different 
in each case of sexual abuse, it is necessary that counselors be flexible during the process. Example statements made by participants in this vein are as follows:

The occurrence of every case of sexual abuse and the impact that it has on the individual are wholly personal and can't be pigeonholed into a single category. It's necessary to be flexible by keeping in mind the trauma that a person subject to sexual abuse has experienced. (131T)

Because each individual reacts differently to abuse, one needs to be well-versed in a variety of practices and methods. Some people are able to recount the event during their first session whereas others may require several sessions in order to do so. (211A)

\section{Theme 3: Emphasizing child's innocence}

One of the more preferred types of interventions used by counselors is to emphasize that the individual is innocent. Participants stated that individuals subject to sexual abuse tended to feel guilty for what happened and that those individuals carrying a sense of guilt were reluctant to recount how the event transpired. Example statements by participants in this vein are as follows:

Approaching a child who has been subject to abuse with one's own prejudices will only cause him to develop a guilt complex, and this what most hinders the process from running smoothly. As such, it's absolutely critical that they are made to feel that they're innocent. (121F)

In this regard, I think that the most important thing is that they feel innocent. I think that if they're able to perceive themselves as innocent, they'll feel more comfortable and be able to describe how the event transpired without difficulty. (231E)

\section{Theme 4: Directing the process in an appropriate manner}

During the interviews, the counselors emphasized that it was necessary to use one's communication and counseling skills in such a manner so as not to make the child feel as if he were being interrogated. Example statements made by the counselors in this regard are as follows:

A counselor interacting with a child subject to sexual abuse needs to be first and foremost flexible and, instead of exhibiting the attitude of a detective, needs to try to reduce the trauma experienced by the child by using easily understood language. We should work to ensure that the least amount of damage is done to the child as a result of this event. (122J)

The process needs to be directed in such a way that seeks to preserve the child's physical and psychological health. In directing the process, the counselor needs to eschew prejudices, not fear succumbing to peer pressure, and act in accordance with professional ethics. (211A)

\section{Theme 5: Notification}

The counselors stated that all children and families needs to receive education on how to prevent sexual abuse. They also stated that children, families, and, most particularly, school administrators and teachers needed to undergo an informational training program detailing what procedures they should follow in the event of sexual abuse. Example statements by participants in this vein are as follows:

Children and their parents need to attend workshops on private areas, or so-called intimacy education, from an early age in particular. (231E)

Schools need to provide education about this issue to students, parents, and teachers. Students, parents, and teachers also need to be informed about what to do if such an event happens. (211P)

Parents need to be informed about how they should act in the event of abuse. (112C) 


\section{Theme 6: Forcing the child}

Of the interventions the one that counselors find to be the most ill-advised is to adopt a coercive attitude during conversations and force the child to recount what he experienced. Participants stated that since children have undergone a traumatic experience, they are very sensitive and therefore will be negatively affected by any attempts at forcing them to speak. Example statements by participants in this regard are as follows:

Forcing the child or constantly calling him to the office to extract an account of the event is contrary to our professional ethics. The child has already been subject to a traumatic experience and if we try to coerce him to speak about it, we'll cause more harm. (221D)

Because sexual abuse is a traumatic experience in which a child was forced to perform certain actions, forcing a child to speak may cause him to relive that trauma. We have to wait for the child to be ready to speak, accepting that the child has his own free-will. (231M)

\section{Theme 7: Ending the conversation}

Another type of action considered inappropriate by counselors in regard to dealing with sexual abuse cases is take down an account of the event and then end the communication after passing it on to the appropriate authorities. The counselors participating in the study stated that it was necessary to continue dialogue, provide psychological support, and to follow up on the child. Example statements by participants in this regard are as follows:

I think it's wrong to end dialogue because communication needs to continue in order to provide psychological support to a child subject to abuse. (112C)

It's absolutely wrong to put an end to the dialogue considering the process complete and acting as if everything were back to normal will only cause a complete psychological meltdown in the child. (121F)

\section{Discussion, Conclusion, and Recommendations}

An examination of the qualitative findings reveals that the intervention approaches used by psychological counselors in cases of sexual abuse can be grouped under two separate factors and that there is a meaningful relationship between these two factors. The direction and level of the relationship between the two factors further indicates that the counselors have a consensus regarding intervention approaches. Upon examination of both factors' Z-scores, we observe that the most preferred counseling interventions are (i) to emphasize that the child's body is valuable, (ii) to be flexible during the process, and (iii) to emphasize the child's innocence. Developing a standard draft guiding counselors' conversations with children subject to sexual abuse during counseling sessions and educating them on specific counseling interventions will aid them in properly directing the process (Jones, Cross, Walsh, \& Simone, 2005; Gümüş, 2017; Doğan \& Bayar, 2018). In designing such a framework, however, it is critical that counselors be made aware that each case of sexual abuse is different and that they must remain flexible (Gümüş, 2017).

An examination of the quantitative findings reveals the subthemes most referred to by the counselors in regard to their most preferred counseling interventions (the 1st main theme) were (i) emphasizing that one's body is valuable, (ii) being flexible, and (iii) emphasizing innocence. Children subject to sexual abuse develop a negative perception regarding their body, considering it to be without value (Bulut, 2016). Here, it is vital that children receive the message that their body is valuable and that counselors remain flexible in their attempts to extract an account of sexual abuse from them. The behaviors exhibited by a child subject to sexual abuse cannot be scrutinized under a single specific category because the effects of such an event differ from child to child. Consequently, it is essential for counselors to develop a flexible, patient attitude in order to collect an accurate account of events (Gümüş, 2017). Children subject to sexual abuse are known to have difficulties explaining how events transpired. One of the reason for such difficulties is the child's sense of self- 
esteem has been deeply shaken. Since such children consider the event to be a shameful secret and fear that by revealing the even to their family, they will be subject to rejection or blame from what had happened, the most important thing a counselor can do to facilitate a child's recounting of the event is to ensure that he has embraced the fact that he is innocent.

In regard to their thoughts on the issue (the 2nd main theme), the subthemes counselors most referred to were (i) directing the process in an appropriate manner and (ii) notification. Counselors stated that the process needed to be directed in a proper manner, articulating that appropriate communication and counseling skills played a critical role in the process. Furthermore, they had reached a consensus regarding the necessity to reassure the child and to adopt a flexible attitude when dealing with such cases. Without inducing an atmosphere of fear and panic, counselors need to minimize potential problems from emerging during the process and work not only to reduce the negative emotions experienced by the child but to return the child's emotions (Olshaher, Jackson, \& Smock, 2001). Using appropriate counseling interventions during conversations held with children aids them in providing more accurate information more quickly. Children should be asked open-ended question that provide encouragement and should not be corrected in their language use or choice of words when recounting the event. By paying attention to and recording children's facial expressions, posture, gestures, and non-verbal signals, an even greater amount of information may be collected (Gümüş, 2017).

The counselors stated that they felt individuals, families, and relevant school staff members lacked information on the process dealing with sexual abuse and that they needed to be educated about sexual abuse by psychological counselors. In terms of preventative actions, children need to educated from a young age on how to protect themselves from sexual abuse. To this end, schools need to devise and implement educational programs (e.g., intimacy education, personal safety, the ability to say no) from an early age in order to cultivate conscious children equipped with the proper tools to protect themselves (Çeçen, 2007). These educational programs should be provided to parents and teachers in addition to children. This way, a mutual definition for sexual abuse will be developed and a shared desire to prevent sexual abuse will flourish (Bulut, 2016). Providing the necessary training to children's classroom teachers in recognizing the signs of abuse, its risk factors, and the process to follow in the event of such an occurrence will constitute an important step in facilitating the early disclosure of such cases (Doğan \& Bayar, 2018).

The most important point in this regard is that educators, like other individuals in society, are legally required to report any instance of child abuse to the appropriate authorities. According to the Turkish Penal Code, reporting child neglect and abuse is legally mandated for all citizens by Law No. 278 and for all public employees by Law No. 279 and those public employees failing to report such instances are subject to legal penalties (Dağlı \& İnanıc1, 2011). School administrators, teachers, and parents need to be informed about the process dealing with sexual abuse. One of the biggest problem in cases of sexual abuse is the child's confusion regarding to whom to reveal the event. Educational workshops regarding how the reporting and postreporting process will transpire need to be provided to students, teachers, and parents (Aksel \& Irmak, 2015).

The two subthemes most referred to by counselors under undesirable counseling interventions (the 3rd main theme) were (i) not forcing the child and (ii) ending the conversation. Forcing the child to recount the event, engaging in efforts to substantiate the event, and ending the conversation were intervention types considered inappropriate for use when dealing with cases of sexual abuse by the majority of counselors participating in the study. Despite the existence of a conducive atmosphere and use of the correct interventions, some still are still hesitant to speak about sexual abuse, in which case coercing the child would be an incorrect approach. If necessary, the current session can be ended and a future session arranged. Allowing the child to choose what time to meet may be a good choice in terms of allowing him to express himself (Saywitz, Lyon, \& Goodman, 2011). Continuing dialogue following the conclusion of judicial 
proceedings is central in helping the child return to normal and to feel better psychologically. These conversations facilitate the child in his attempt to regain control of his life and in dealing with the trauma experienced. The continuation of such conversations is also integral in repairing damaged human relations and in allowing the child to be able to reestablish relationships of trust (Akgül, 2015).

Based on the study's qualitative and quantitative findings, it is possible to devise a standard process and method for psychological counselors to follow when dealing with cases of sexual abuse. Accordingly, roadmap can be devised by conducting interviews with field experts. Reaching students suspected to have been subject to sexual abuse, formulating appropriate interview standards, notifying the appropriate bodies and individuals, and both the content and ethical dimensions of interviews with children can be determined.

Preventive measures may also be taken in order to prevent occurrences of sexual abuse. Educational programs designed for students, parents, and teachers can be organized. Being the most frequently contacted in instances of sexual abuse, school counselors can be provided special training by field experts to increase their awareness of the early warning signs of sexual abuse. A counselor that has received specialized training is critical in preventing occurrences of sexual abuse altogether and, in the unfortunate event that sexual abuse has occurred, in recognizing and revealing it during therapy sessions. It is recommended that future studies use qualitative and quantitative approaches to research the problems encountered by counselors during interviews and then provide recommendations for how to solve these problems. 


\section{Appendix}

\section{Appendix 1. Counseling Interventions Survey}

1-Every case of sexual abuse has its own conditions. We should first and foremost be flexible in order to attain accurate information and to be helpful.

2-We should not insist on the issue if the child wishes not to speak about it.

3-We should not encourage the child to speak by hinting to the existence of sexual abuse.

4-We should not force the child subject to sexual abuse to give an accurate account of it in the event that $\mathrm{s} /$ he refuses to speak with us.

5-We should use a scientific language during our conversations with children who have been subject to sexual abuse.

6-We should ask closed and guiding questions, in order to ensure that the child who is sexually abused gives us correct information.

7-We should not conduct in-depth interviews with children to prove sexual abuse.

8-Because there are signs of trauma in every child who has been subject to sexual abuse, we should be able to recognize the signs to understand abuse.

9-In the event that the child subject to sexual abuse is very young, we should use indirect methods to obtain information from the child.

10-We should not end the dialogue upon receiving an account of the event and passing it on to the appropriate authorities.

11-We should inform the child subject to sexual abuse that the same thing could happen to other children.

12-We should instill in the child subject to sexual abuse the notion that his/her body is valuable and belongs to him/her alone.

13-We should emphasize to the child subject to sexual abuse that $\mathrm{s} / \mathrm{he}$ is innocent.

14-We should not use the exposure technique in our conversations with children subject to sexual abuse.

15-We should consider it normal for a child subject to sexual abuse to reflect his anger outwardly.

16-We should be aware of the messages conveyed through children's body language 


\section{REFERENCES}

Akgül, E. (2015). A study about reportıng status of child sexual abuse by the staff workıng in preschool education centers. (Unpublished Master's Thesis). Hacettepe University, Ankara,Turkey.

Aksel, Ş., \& Irmak, T. Y. (2015). Çocuk cinsel istismarı konusunda öğretmenlerin bilgi ve deneyimleri [Teachers' knowledge and experience about child sexual abuse]. Ege Eğitim Dergisi, 373-391.

Alaggia, R. (2004). Many ways of telling: Expanding conceptualizations of child sexual abuse disclosure. Child Abuse \& Neglect, 28(11), 1213-1227.

Bilgin, Ö. (2015). Determination of the Psychosocial Situations of the Sexually Abused Children in terms of the Characteristics of the Abuse. (Unpublished Master's Thesis). Selçuk University, Konya, Turkey.

Bulut, S. (2016). Çocuk cinsel istismarı hakkında bir derleme [Defınıng sexual abuse and the followıng procedure]. Türk Psikolojik Danışma ve Rehberlik Dergisi, 3(28), 139-156.

Bulut, S. (2018). Çocuk cinsel istismarı nedir?. [What is child sexual abuse? ]. Bakış Ege, (1), 38-40.

Büyüköztürk, Ş., Çakmak, E. K., Akgün, Ö. E., Karadeniz, Ş., \& Demirel, F. (2017). Bilimsel araştırma yöntemleri ( 23. bs.). Ankara: Pegem Akademi Yayıncılık.

Çeçen, A. R. (2007). Çocuk cinsel istismarı: Sıklığı, etkileri ve okul temelli önleme yolları. [Child Sexual Abuse: Prevalence, Effects and School Based Prevention]. Uluslararası İnsan Bilimleri Dergisi, 1, 1-17.

Dağlı, E. T., \& İnanıcı, M. A. (2011). Hastane temelli çocuk koruma merkezleri için başvuru kitabı, ihmal ve istismara uğrayan çocuğa bütüncül yaklaşım (1. bs.). Ankara: UNICEF Türkiye Ülke Ofisi.

Demir, F., \& Kul, M. (2011). Modern bir araştırma yöntemi olarak; Q metodu. Ankara: Adalet Yayınları.

Doğan, T., \& Bayar, Ö. (2018). Çocuk cinsel istismarı: geleceğin öğretmenleri ve okul psikolojik danışmanları ne kadar biliyor?. [Chıld sexual abuse: how much do future teachers and school counselors know?]. Journal of International Social Research, 11(55).

Gümüş, A. E. (2017). Çocuk cinsel istismarı şüphesinin bildirimi öncesinde çocukla yapılacak ilk görüşme. [The first interview with child ahead of reporting suspected child sexual abuse]. Klinik Psikiyatri Dergisi, 20(1), 45-58.

Gündüz, H. Ç., \& Yıldız, A. D. (2016). Cinsel istismarın önlenmesinde cinsel eğitimin önemi. Accessed from: https://www.researchgate.net/publication/323657089. Date of Access: 24 April 2019.

Günes, H. (2002). Cinsel istismara yönelik müdahaleler. Türk Psikoloji Bülteni, 8(24-25), 77-80.

Jones, L.M., Cross, T.P., Walsh, W.A., \& Simone, M. (2005). Criminal investigations of child abuse: The research behind "best practices." Trauma, Violence, \& Abuse, 6(3): 254-268.

Liamputtong, P. (2009). Qualitative data analysis: Conceptual and practical considerations. Health Promotion Journal of Australia, 20(2), 133-139.

Lyon, T. D., \& Ahern, E. C. (2011). Disclosure of child sexual abuse. The APSAC handbook on child maltreatment, 3, 233-252.

McKeown, B., \& Thomas, D. B. (2013). Q methodology (Vol. 66). Sage publications.

Moore, D. (2005). Telling the Secret: Channels of communications for the recovering survivors of child sexual abuse. Accessed from: http://www.malesurvivor.org/ Professionals/Articles/telling.htm. Date of access: 15 April 2018. 
Olshaher, J. S., Jackson, M. C., \& Smock, W. S. (2001). Forensic Emergency Medicine. Loppincott Williams and Wilkins. Wolter Kluwer Company, New York.

Polat, O. (2007). Tüm boyutlarıyla çocuk istismarı 1: Tanımlar. Ankara: Seçkin Yayıncılık.

Polat, O. (2018). Çocuk istismarına yönelik rapor-2. Accessed from: http://imdat.org/wpcontent/uploads/2018/04/Rapor-Çocuk-İsmarı-tam?า v2_cleancopy.pdf Date of Access: 25 April 2019.

Saywitz, K. J., Lyon, T. D., \& Goodman, G. S. (2011). Interviewing children. The APSAC handbook on child maltreatment, 3, 337-36. 